\title{
Observational Study of a Monsoon Depression Developed Over the Bay of Bengal during Summer MONEX
}

\author{
By Tsuyoshi Nitta and Kooiti Masuda \\ Geophysical Institute, University of Tokyo, Tokyo 113, Japan \\ (Manuscript received 12 April 1981, in revised form 3 July 1981)
}

\begin{abstract}
Three dimensional structure of a monsoon depression developed over the Bay of Bengal during summer MONEX is examined by the use of aircraft dropwindsonde and conventional upper-air observations. Wind, temperature and relative humidity data are interpolated objectively at $1^{\circ}$ latitude/longitude grid points over the area of $11^{\circ}-24^{\circ} \mathrm{N}$ and $80^{\circ}-93^{\circ} \mathrm{E}$ and at $25 \mathrm{mb}$ pressure levels from the surface to the $500 \mathrm{mb}$ level for the period 3-8 July 1979.

The depression formed over the Bay of Bengal at about $19^{\circ} \mathrm{N}$ and $90^{\circ} \mathrm{E}$ on July 6 and moved westward with about $2^{\circ}$ day $^{-1}$ speed and reached a coast line of India on July 8 . The developed depression has the maximum vorticity of about $1.5 \times 10^{-4} \mathrm{~s}^{-1}$ and a warm core slightly to the east of the depression center. Horizontal convergence and rising motion occur to the west of the depression center where active convective clouds exist. The horizontal axis of the depression is inclined from southwest to northeast. The depression transports heat and momentum northward and gains its kinetic energy from the mean zonal flow.

The analysis during the pre-formation period shows that there exists large positive vorticity of about $5 \times 10^{-5} \mathrm{~s}^{-1}$ in the area over the bay which is close to the area of depression formation. This large positive vorticity is caused by both the existence of a weak trough and the meridional gradient of the zonal flow.

The latitude-height distribution of the zonal wind averaged over the Bay of Bengal for the pre-formation period shows that the necessary condition for instability of the zonal flow is satisfied. A stability analysis of the zonal flow averaged in the lower troposphere below $500 \mathrm{mb}$ indicates that the flow is barotropically unstable with the maximum growth rate at about $3,500 \mathrm{~km}$. The unstable wave has several similar characteristic features to those observed.
\end{abstract}

\section{Introduction}

Monsoon depressions are common and important meteorological phenomena over the Indian monsoon area during summer. The long term statistics show that about two monsoon depressions per month form during the monsoon months. They generally form over the Bay of Bengal, move westward or northwestward and bring large amounts of precipitation over India.

Krishnamurti et al. (1975) analyzed a developed depression during August, 1968 and obtained detailed vertical structure of the depression. The depression has the horizontal scale of about 2,000 $\mathrm{km}$, the vertical scale of about $10 \mathrm{~km}$ and westward propagation of about $5^{\circ}$ longitude day ${ }^{-1}$. There exist a well defined cold core in the lower troposphere and a warm core in the upper troposphere. Rising motion occurs to the west of the trough line and desending motion to the east. Godbole (1977) constructed a composite three dimensional structure of the monsoon depression using five monsoon depressions of 1973 and obtained similar characteristics of the depression to those by Krishnamurti et al. (1975).

Krishnamurti et al. (1976) further performed numerical experiment of the monsoon depression and showed that the monsoon depression is primarily maintained by condensation heating. Krishnamurti et al. (1977) stressed the importance of an interaction of the large-scale standing oscillation with westward propagating smaller scale disturbances for the formation of monsoon disturbances (including depressions) based on an analysis of 43 years of surface pressure data. Shukla (1977) investigated barotropic-baroclinic instability of mean zonal flow during summer monsoon and found an unstable wave at about 
$150 \mathrm{mb}$. However, he could not obtain unstable waves similar to the observed monsoon depressions which have their maximum amplitude at the lower levels. Shukla (1978) continued to study instability of the monsoon flow including diabatic heating due to cumulus clouds. He found an unstable wave generated mainly by condensation heating which has similar characteristics to those of the observed monsoon depressions, but the mechanism for scale selection was not clear in his results.

Most of the previous analyses for the monsoon depression were based on observations over India where the depression was fully developed or inclined to dissipate. However, none of the analyses for the formative stage of the monsoon depression have been made because of sparsity of observations over the Bay of Bengal. The Second Phase of the Summer MONEX-Bay of Bengal Experiment-has been conducted in July 1979. The main objective of this experiment is to gather observational data for the monsoon depression over the Bay of Bengal where the monsoon depression usually forms. Two research aircrafts, the NCAR Electra and the NOAA P-3, released dropwindsondes from the flight levels over the Bay of Bengal. One monsoon depression formed and developed over the Bay of Bengal on July 6, 1979 and moved westward slowly with the speed of about $2^{\circ} \mathrm{day}^{-1}$. Special aircraft observations taken during the period from July 3 to July 8, 1979 provided us an unique data set for the monsoon depression during the period from the pre-formation stage to the developed stage.

Nitta and Murakami (1980) have reported preliminary results of the structure and energy cycle of the depression based on their works at Summer MONEX Operation Center during the experiment. This study is an extention of the study of Nitta and Murakami (1980) to obtain the detailed three dimensional structure of the monsoon depression using an objective analysis method. An instability analysis of the observed monsoon flow over the Bay of Bengal will be also examined to study the mechanism for initiation of the monsoon depression.

\section{Data and method of analysis}

Aircraft dropwindsonde observations measured during the period from July 3, 1979 to July 8, 1979 are mainly used for analysis in this study. Two research aircrafts, the NCAR Electra and the NOAA P-3, participated in the Bay of Bengal
Experiments during the summer MONEX. Electra and P-3 released 41 and 43 dropwindsondes, respectively, during the analyzed period. Upperair wind, temperature and relative humidity (or dew point temperature) were measured by the dropwindsondes and these data were printed out during the flight missions.

In addition to the dropwindsonde data, conventional upper-air data over western India transmitted to Japan Meteorological Agency are used for analysis. Wind, temperature and dew point temperature data are reported at standard and significant pressure levels. The upper-air data at 0000 GMT (0600 LT) and 1200 GMT (1800 LT) are averaged for the mixed use with the dropwindsonde observations which are obtained during daytime.

Since most of the flight levels of Electra and P3 are around $500 \mathrm{mb}$, analyses are limited below $500 \mathrm{mb}$. Basic meteorological parameters such as temperature, relative humidity and east-west and north-south wind components for each sounding are linearly interpolated at constant pressure levels with a $25 \mathrm{mb}$ interval from $1,000 \mathrm{mb}$ to $500 \mathrm{mb}$. The parameters at each pressure level are interpolated at $1^{\circ}$ latitude/longitude grid points in the area of $11^{\circ} \mathrm{N}-24^{\circ} \mathrm{N}$ and $80^{\circ} \mathrm{E}$ $93^{\circ} \mathrm{E}$ (except on July 5 where the area of $11^{\circ} \mathrm{N}$ $24^{\circ} \mathrm{N}$ and $82^{\circ} \mathrm{E}-95^{\circ} \mathrm{E}$ is used) using the Cressman's (1959) successive correction method. The areal average of the observations is taken as an initial guess field and scan radii of 3, 2, 1.6, 1.4, 1.2 and 1.0 times the mean station separation ( $\sim 2$ degrees) are used. These ratios of scan radii are the same as those employed by Ogura et al. (1979) for their analysis of organized convective systems during GATE. Fig. 1 shows an example of wind vectors interpolated at grid points and locations of the upper-air soundings at $700 \mathrm{mb}$ on July 7.

The variables at the $1^{\circ} \times 1^{\circ}$ grid points for each pressure level are fitted by using twodimensional cubic spline curves and their relative vorticity and divergence are computed from horizontal derivatives of the fitted curves. Vertical $p$-velocity is computed from the continuity equation by assuming that the vertical velocity vanishes at $975 \mathrm{mb}$, because the surface observations were not precisely measured by the dropwindsondes. No correction of the horizontal divergence and the vertical $p$-velocity is employed in this study. Computations of the vertical velocity using the continuity equation from below would be liable to include errors especially in the upper layer 


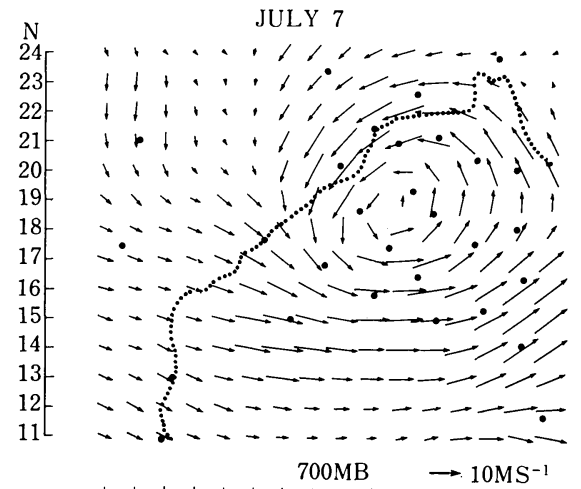

$78 \frac{1}{1} \frac{1}{1} \frac{1}{1} \frac{1}{1} \frac{1}{1} \frac{1}{1} \frac{1}{1} \frac{1}{1}$

Fig. 1 Wind vectors at $700 \mathrm{mb}$ on July 7 determined by the objective analysis. Black circles denote locations of upperair soundings. The dotted line denoted a coast line of India.

due to errors of wind observations and interpolation processes. However, the distributions of the computed vertical velocity generally correspond well to those of relative humidity and cloud pictures taken by the meteorological satellite as will be shown in the next section, and hence the errors of the computations might be small in this study.

Since the networks of the dropwindsonde observations on July 7, in which the depression developed into a mature stage, were most dense during the analyzed period, most of the analysis for the structure of the depression was made using the data on July 7. The data for the other period were used to examine time evolution of the depression.

\section{Three dimensional structure of a developed depression}

\section{$3.1 \quad$ Structure on July 7}

The depression was formed over the Bay of Bengal at about $90^{\circ} \mathrm{E}$ and $19^{\circ} \mathrm{N}$ on July 6 , moved slowly westward and reached the Indian subcontinent on July 8 . On July 7 , the depression developed into a mature stage over the Bay. 22 dropwindsonde released by two research aircrafts fully covered the depression. The depression center at $700 \mathrm{mb}$ lies at about $19^{\circ} \mathrm{N}$ and $88^{\circ} \mathrm{E}$ as shown in Fig. 1. A horizontal axis of the cyclonic circulation tilts slightly from southwest to northeast indicating northward transport of westerly momentum. Fig. 2 describes relative vorticity at $700 \mathrm{mb}$. The depression has a large relative vorticity with a maximum amplitude of about $1.5 \times 10^{-4} \mathrm{~s}^{-1}$ around the center.

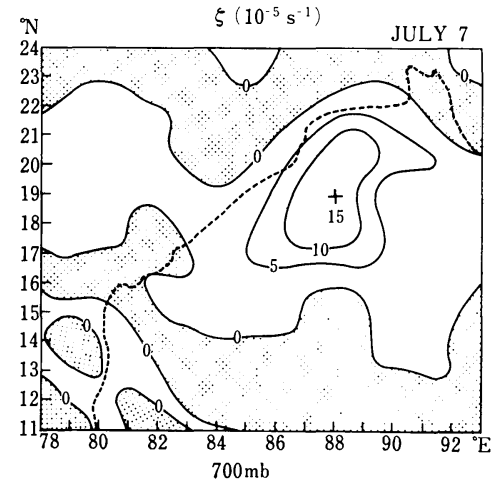

Fig. 2 Distribution of the relative vorticity at $700 \mathrm{mb}$ on July 7 . Shaded areas denote negative vorticity. + denotes the center of the monsoon depression.

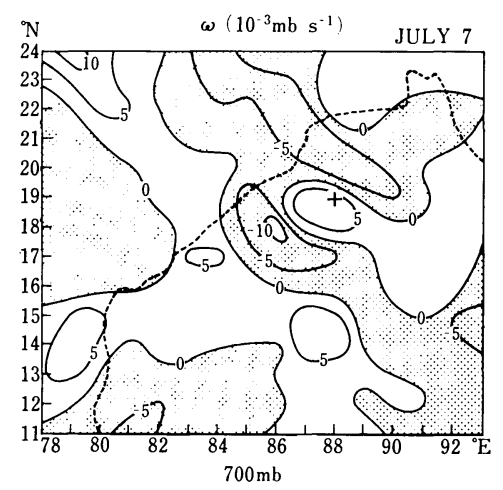

Fig. 3 Distribution of the vertical $p$-velocity at $700 \mathrm{mb}$ on July 7 . Shaded areas denote rising motions. + denotes the center of the monsoon depression.

Fig. 3 shows the distribution of the vertical $p$-velocity at $700 \mathrm{mb}$. Downward motion exists around the depression center. Large upward motion lies both to the southwest and to the northwest of the center. The area of the strong upward motion to the southwest of the center corresponds to the confluence zone as shown in Fig. 1.

Fig. 4 shows a cloud picture taken by GMS (Geostationary Meteorological Satellite) of Japan at 0000 GMT 7 July 1979, a few hours earlier than the research aircraft mission of 7 July. Active cloud systems exist in the area at about $88^{\circ} \mathrm{E}$ and $20^{\circ} \mathrm{N}$ and the area from southwest to south of the depression center. These active cloud areas generally correspond to those of the strong upward motion as shown in Fig. 3. It should be noted that there exists cloud free region at about $88^{\circ} \mathrm{E}$ and $18^{\circ} \mathrm{N}$ which may correspond 


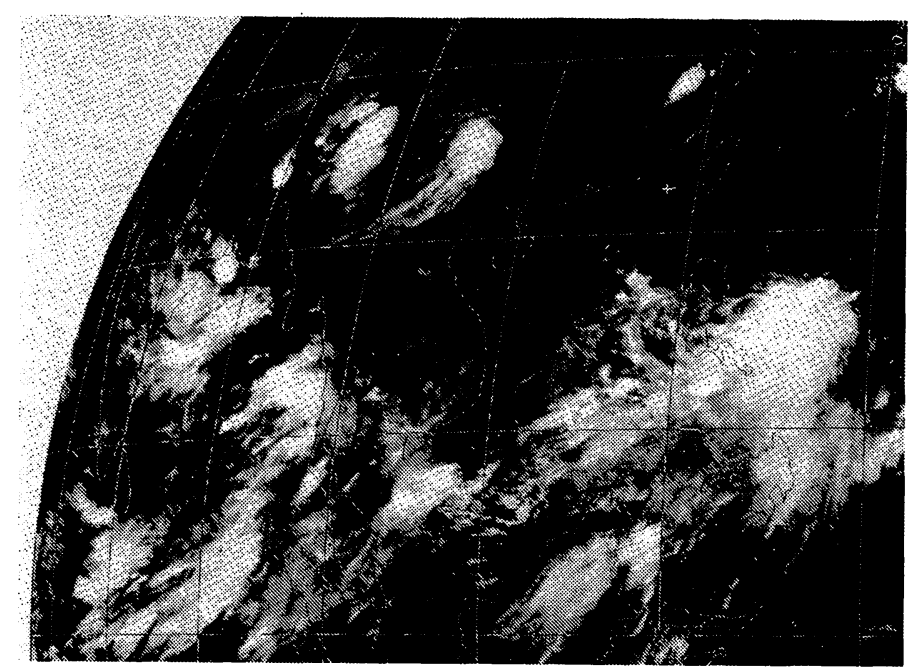

Fig. 4 GMS cloud picture at 0000 GMT 7 July 1979. The Bay of Bengal is located near the lefthand tip of the picture.

to the area of downward motion around the depression center.

In order to investigate more details of the vertical structure of the depression, longitudeheight cross sections of the meteorological parameters are constructed at $19^{\circ} \mathrm{N}$ where the depression center is located. Fig. 5 shows a vertical cross section of the $v$-component. Maximum southerly and northerly winds of about $13 \mathrm{~m} \mathrm{~s}^{-1}$ exist in the lower troposphere near $800 \mathrm{mb}$. A zero line corresponding to the axis of the depression center tilts slightly westward with increasing height. The wind field at $600 \mathrm{mb}$ (not shown) shows that the depression center is located at $18^{\circ} \mathrm{N}$ and $87^{\circ} \mathrm{E}$ indicating the southwestward inclination of the axis with height.

Fig. 6 shows a cross section of the relative vorticity. Large positive vorticity exists at about $88^{\circ} \mathrm{E}$ and extends almost vertically through the whole lower troposphere. Fig. 7 shows a cross section of the vertical $p$-velocity. As described in Fig. 3 the downward motion dominates the area around the depression center $\left(88^{\circ} \mathrm{E}\right)$ and the maximum upward motion occurs to the west of the center. A cross section of the relative humidity is shown in Fig. 8. Generally, moist air exists over the Bay of Bengal (to the east of $85^{\circ} \mathrm{E}$ ) and dry air exists over the continental area (to the west of $85^{\circ} \mathrm{E}$ ). It should be noted that the dry air appears above $800 \mathrm{mb}$ near the depression center $\left(\sim 88^{\circ} \mathrm{E}\right)$ where the strong downward motion is found (Fig. 7). The longitudinal variations of the relative humidity and the vertical velocity above $700 \mathrm{mb}$ around the depression

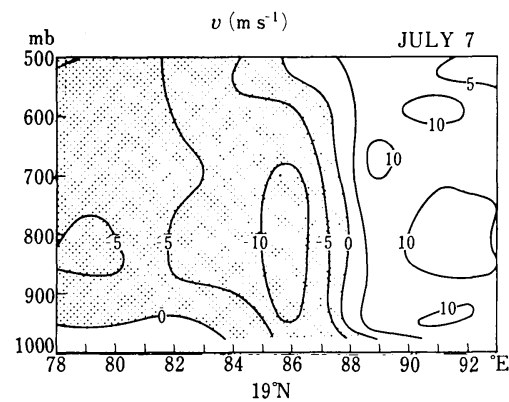

Fig. 5 Longitude-height section of the meridional wind component at $19^{\circ} \mathrm{N}$ on July 7 . The shaded area denotes northerly winds.

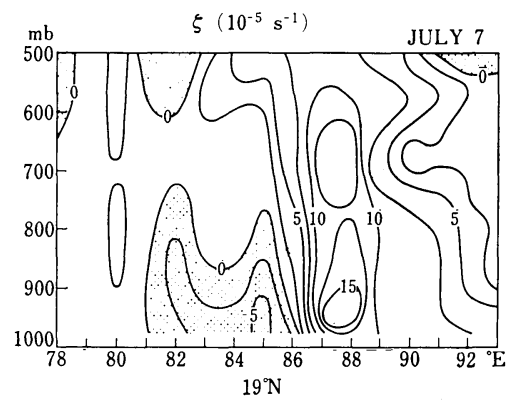

Fig. 6 Longitude-height section of the relative vorticity at $19^{\circ} \mathrm{N}$ on July 7 . Shaded areas denote negative relative vorticity.

center are correlated well with each other.

Fig. 9 shows a cross section of the temperature deviation from the zonal mean values. Warm area lies on and slightly to the east of the depression center suggesting that the depression has a warm 


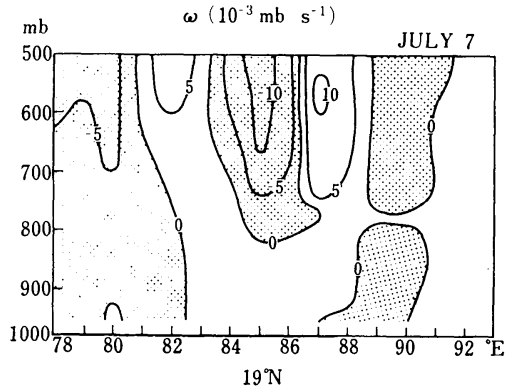

Fig. 7 Longitude-height section of the vertical $p$-velocity at $19^{\circ} \mathrm{N}$ on July 7 . Shaded areas denote rising motions.

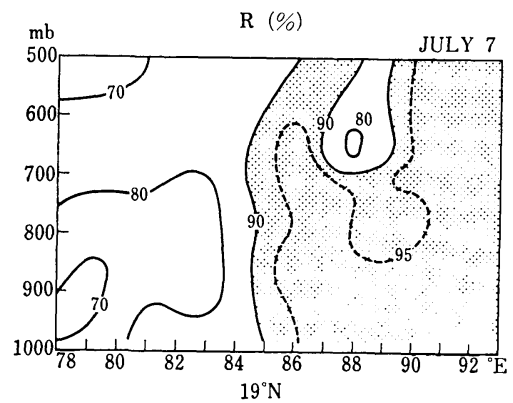

Fig. 8 Longitude-height section of the relative humidity at $19^{\circ} \mathrm{N}$ on July 7 . Areas with relative humidity higher than $90 \%$ are shaded.

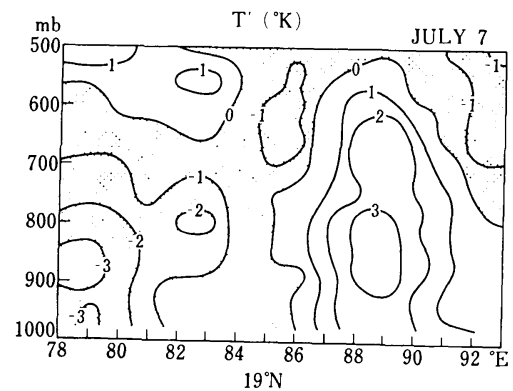

Fig. 9 Longitude-height section of the temperature deviation at $19^{\circ} \mathrm{N}$ on July 7 . Shaded areas denote negative deviations.

core in the lower troposphere. The temperature structure around the depression center indicates that the heat is transported northward due to the depression. The warmest area generally corresponds to the area of the sinking motion as shown in Fig. 7. It may occur that the adiabatic warming is resulted from the downward motion around the depression center.

The temperature structure obtained in this study contradicts that obtained previously by other studies. Krishnamurti et al. (1975) and
Godbole (1977) have obtained cold-core structure in the lower troposphere and a warm core in the upper troposphere. Their studies were mostly based on the observations over India where depressions were usually fully developed. However, this study is mainly based on the dropwindsonde observations over the Bay of Bengal for the early stage of the depression development. We may suppose that the difference of the temperature structure is resulted from the different stages of the development of the depression. However, exact reasons of the temperature difference are not clear and should be further investigated in future.

The cross sections of the vertical velocity and temperature deviations is Figs. 7 and 9 show that deviations of $\omega$ and $T$ from the zonal mean values appear to be positively correlated suggesting energy conversion from kinetic energy to potential energy of the depression. Krishnamurti et al. (1976) carried out a 48 hour forecast of the monsoon depression by using a multi-level primitive equation model and concluded that the monsoon depression was primarily maintained by condensation heating. The direction of the energy conversion suggested in this study seems to be opposite to their result. However, our analysis is limited below $500 \mathrm{mb}$ and full comparison with their result of energy conversion in the whole troposphere is beyond the scope of our study.

\subsection{Structure on July 6 and July 8}

The structure of the developed depression is also analyzed by using the observation on July 6 and July 8, although the data coverage during these periods is not so excellent as that on July 7. Figs. 10 and 11 show vertical cross sections of the relative vorticity and the vertical $p$-velocity at $19^{\circ} \mathrm{N}$ on July 6 and $20^{\circ} \mathrm{N}$ on July 8 , respectively. The maximum relative vorticity lies at $90^{\circ} \mathrm{E}$ on July 6 and $86^{\circ} \mathrm{E}$ on July 8 indicating the $2^{\circ}$ longitude day $^{-1}\left(2.3 \mathrm{~m} \mathrm{~s}^{-1}\right)$ westward movement of the depression. The magnitudes of the relative vorticity for three days from July 6 to July 8 are the same order of about $1.0 \times$ $10^{-4} \mathrm{~s}^{-1}$. It is noteworthy that the depression has already possessed strong circulation on July 6 when it formed over the Bay of Bengal.

On July 6 , the maximum upward motion occurs slightly to the west of the depression and downward motion exists to the east of it. On July 8, the maximum upward motion lies in front of (to the west of) the center and weak downward motion exists in the middle troposphere behind 

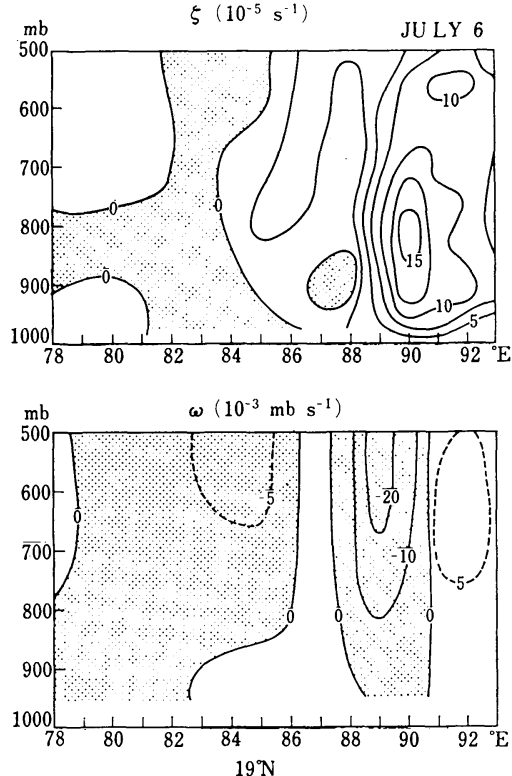

Fig. 10 Longitude-height sections of the relative vorticity (upper) and the vertical $p$-velocity (lower) at $19^{\circ} \mathrm{N}$ on July 6 .
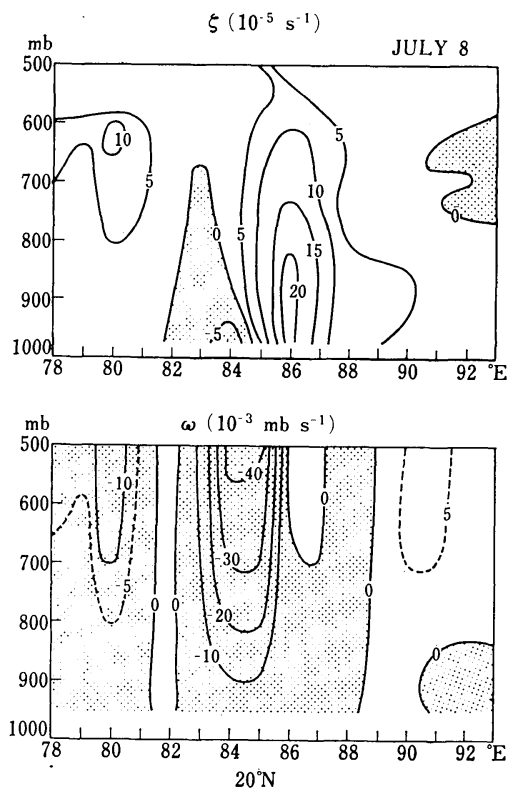

Fig. 11 As in Fig. 10 except at $20^{\circ}$ on July 8 .

(to the east of) the center. The horizontal distribution of the vertical p-velocity on July 8 (not shown) indicates that the area of this weak downward motion is connected to the area of strong downward motion to the north of the center. General features of the vertical velocity associated with the depression on July 6 and July 8 are similar to those on July 7 .

Horizontal distributions of the wind fields on July 6 and July 8 (not shown) show that the horizontal inclination of the trough axis from southwest to northeast increases as the depression moves westward. This indicates that the northward momentum transport due to the depression increases in time. Results of the momentum transport due to the depression will be shown in the next sub-section.

The monsoon depression observed over the Bay of Bengal in this study has many similar characteristic features to those analyzed previously by Krishnamurti et al. (1975) and Godbole (1977) except the temperature structure, i.e., the depression has wind speeds of about 10 to $15 \mathrm{~m} \mathrm{~s}^{-1}$ and the maximum vorticity of about $10^{-4} \times \mathrm{s}^{-1}$, and the rising motion with order of magnitude of $10^{-3} \mathrm{mb} \mathrm{s}^{-1} \sim 10^{-2} \mathrm{mb} \mathrm{s}^{-1}$ occurs to the west of the depression center.

\subsection{Horizontal transports of momentum and heat}

Horizontal distributions of winds and temperature suggest that the momentum and heat are transported northward by the depression as described previously. To confirm these transports qualitatively, momentum and heat transports due to the depression are computed. Deviations of north-south and east-west wind components and temperature from zonal mean values averaged over longitudes of 10 degrees wide whose center corresponds to the depression center are used to compute the transports.

Fig. 12 shows latitude-height distributions of the momentum fluxes on July 7 and July 8 . Since the depression center on July 6 is very close to the eastern boundary of the analysis, computations are not performed for July 6 . The northward momentum flux dominates the whole region on July 7 except in the lower troposphere to the north of the depression center where the southward momentum flux takes place. There exist large northward momentum fluxes in the middle layer around $600 \mathrm{mb}$ to the south of the depression center which result from southwesterlies to the east of the center and northeasterlies to the west. As suggested from the increase of the inclination of the horizontal axis, there exist larger northward momentum fluxes on July 8 than on July 7. Since the mean zonal westerly decreases with increasing latitude, this northward westerly momentum flux indicates that the depression is gaining its kinetic energy from the mean 

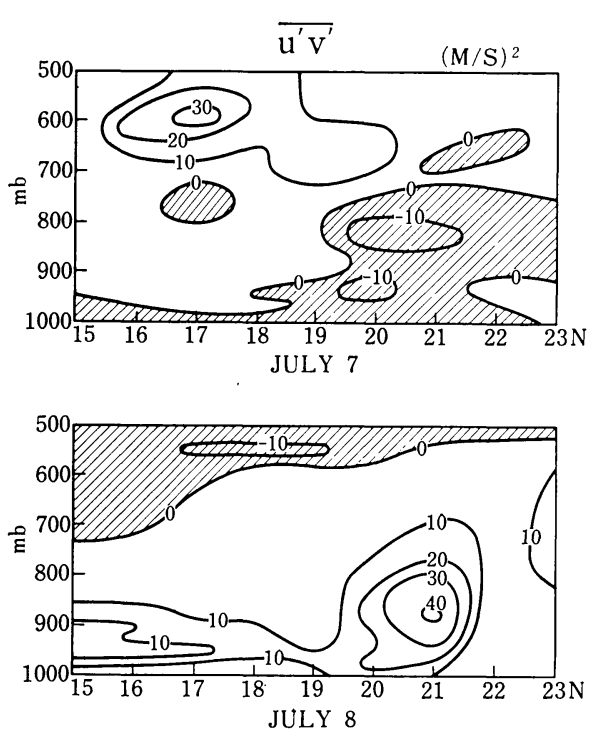

Fig. 12 Longitude-height section of the momentum flux due to the monsoon depression on July 7 (upper) and July 8 (lower). Shaded areas denote the southward momentum flux.

zonal flow. This barotropic process will be discussed in section 5 .

The horizontal heat flux due to the depression is also computed by the same method as the momentum flux. Fig. 13 shows the heat transport on July 7 and July 8 . There exists large positive (northward) heat transport above $850 \mathrm{mb}$ but small negative (southward) heat transport below it on July 7. The results of the positive heat transport above $850 \mathrm{mb}$ agree qualitatively with those of the vertical structure of the $v$-component and temperature described in Figs. 5 and 8. The result of July 8 also shows the northward heat transport, although the distribution has some irregularities probably due to insufficient data density. Since the mean temperature in the middle and lower troposphere over the analyzed area is higher in the north than in the south, the depression transports heat upgradient the mean temperature field in contrast to the downgradient heat transport by the usual mid-latitude cyclones.

Figs. 12 and 13 show that the distributions of momentum and heat transports are significantly different between on July 7 and July 8 . This difference would be partly due to the change of the structure of the depression but partly due to the methods of analysis. The data density on July 8 is not as good as that on July 7 as described previously and the use of 10 degrees
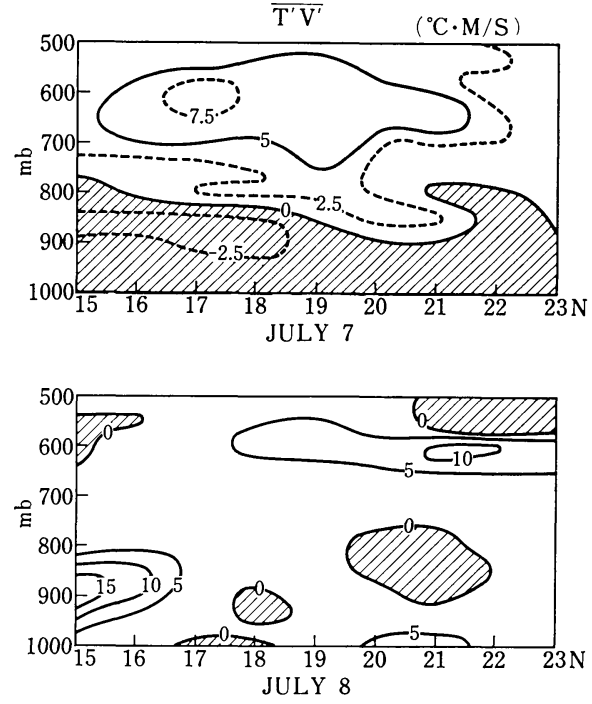

Fig. 13 As in Fig. 12 except for the heat flux. Shaded areas denote the southward heat flux.

length for the zonal mean may not be enough for separation of the depression from the mean field. However, major directions of momentum and heat transports due to the depression are the same for July 7 and July 8 and these results may represent general characteristics of the depression.

\section{Synoptic situation during the pre-formation period}

One of the unique characteristics of the data set used in this study is that this data set covered the pre-formation and formative stages of the monsoon depression over the Bay of Bengal. The depression was formed over the bay on July 6 and has already had strong wind circulations as described in the previous section. There were research flights on July 3 and July 5 corresponding to the pre-formation period. In this section we examine synoptic weather situations for the pre-formation stage based on observations of July 3 and July 5.

Fig. 14 shows the wind vectors and the relative vorticity at $800 \mathrm{mb}$ on July 3, July 5 and July 6 .

There exists a weak trough over the bay on July 3 and July 5. This trough extends from the lower troposphere to the middle troposphere (not shown). Large relative vorticity of about $5 \times$ $10^{-5} \mathrm{~s}^{-1}$ exists at about $90^{\circ} \mathrm{E}$ and $17^{\circ} \mathrm{N}$ where the trough line is located. This large relative vorticity is partly due to a cyclonic circulation associated with the trough and partly due to 


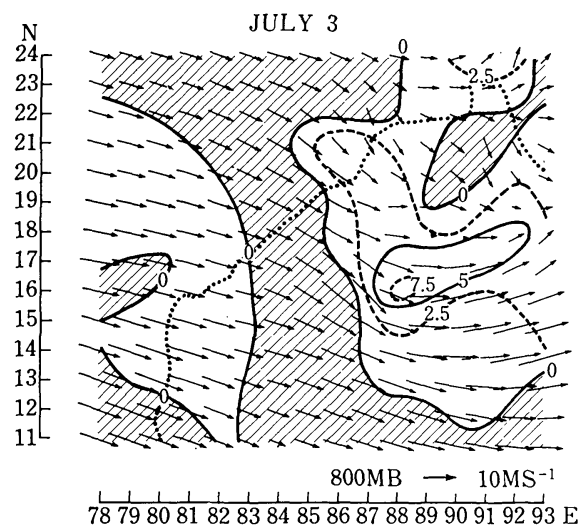

(a)

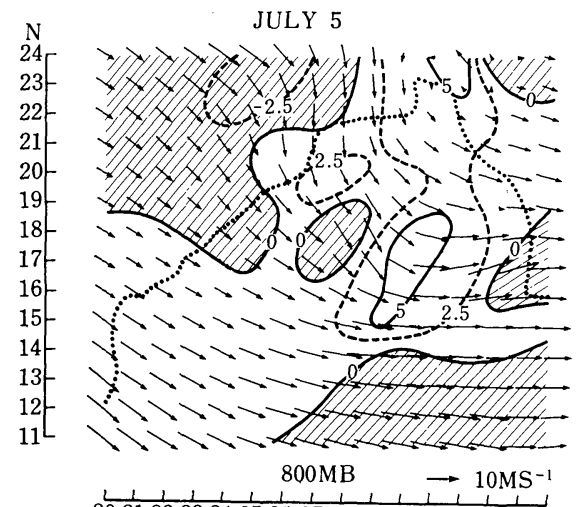

$\frac{1}{80818283848586878889909192939495} \mathrm{E}$

(b)

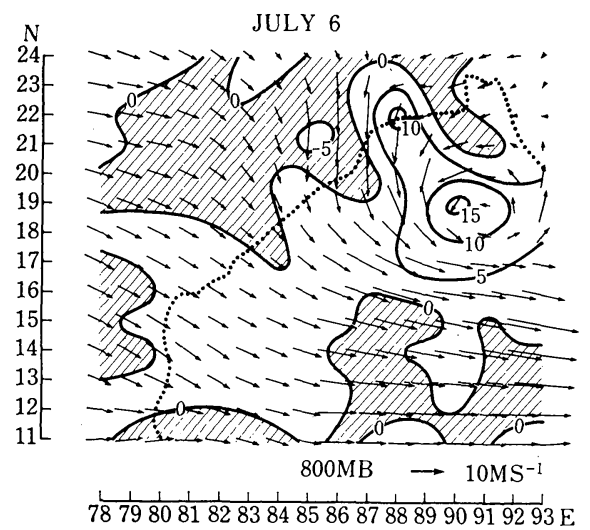

(c)

Fig. 14 Wind vectors and distribution of the relative vorticity at $800 \mathrm{mb}$ on July 3 (a), July 5 (b), and July 6 (c). Shaded areas denote negative relative vorticity.

latitudinal variation of the zonal wind.

On July 6 (Fig. 14c) a closed circulation forms at about $90^{\circ} \mathrm{E}$ and $19^{\circ} \mathrm{N}$ which is about two degrees north of the area of the maximum vorticity of the previous day (Fig. 14b). The amplitude of the relative vorticity on July 6 $\left(1.5 \times 10^{-4} \mathrm{~s}^{-1}\right)$ is about three times larger than that of the pre-formation period. Nearly coincidence of the areas of the maximum relative vorticity during the pre-formation period and the formation period suggests that the existence of the large relative vorticity during the pre-formation period may play important role in the formation of the depression. A possible mechanism of the depression formation due to the horizontal wind shear will be discussed in the next section.

Another noticeable result for the pre-formation period (not shown) is that the upward motion generally exists to the east of the maximum vorticity in contrast to the existence of the upward motion to the west of the depression center after formation. This difference may be closely related to the dynamics of the depression formation but exact reason of this difference is not certain.

\section{Instability of a zonal flow}

The developed depression gains its kinetic energy from the mean zonal flow as described in section 3. There exists large meridional gradient of the vorticity over the Bay of Bengal during the pre-formation period as demonstrated in the previous section. These results suggest that dynamical instability of the zonal flow may be one of possible mechanisms for initiation of the depression. In this section we shall examine stability of the zonal flow over the Bay of Bengal.

Fig. 15 shows the latitude-height distribution of the zonal wind averaged over the region from $83^{\circ} \mathrm{E}$ to $93^{\circ} \mathrm{E}$ on July 3 . There is a westerly maximum in the lower layer around $900 \mathrm{mb}$

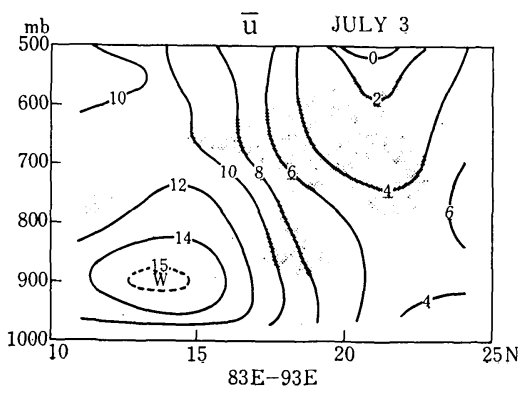

Fig. 15 Latitude-height section of the zonal wind averaged over longitudes from $83^{\circ} \mathrm{E}$ to $93^{\circ} \mathrm{E}$ on July 3. Shaded areas denote areas of negative meridional gradient of the potential vorticity. 
at about $14^{\circ} \mathrm{N}$ and large meridional wind shear exists to the north of it. A necessary condition for instability of a zonal flow with horizontal and vertical wind shear derived by Charney and Stern (1962) is that gradient of potential vorticity changes its sign somewhere in the domain. The gradient of potential vorticity $\bar{q}$ is defined by

$$
\frac{\partial \bar{q}}{\partial y}=\beta-\frac{\partial^{2} \bar{u}}{\partial y^{2}}-\frac{\partial}{\partial p}\left(\frac{f_{0}^{2}}{\sigma} \frac{\partial \bar{u}}{\partial p}\right),
$$

where $\bar{u}$ is the zonal mean wind, $\beta$ the gradient of the Coriolis parameter, $f_{0}$ Coriolis parameter at the reference latitude, $\sigma \equiv-\bar{\alpha}(\partial \ln \bar{\theta} / \partial p), \quad \theta$ potential temperature and $\alpha$ specific volume. The shaded areas in Fig. 15 denote regions of negative $\partial \bar{q} / \partial y$. There exist regions of negative $\partial \bar{q} / \partial y$ at latitudes between $16^{\circ} \mathrm{N}$ and $23^{\circ} \mathrm{N}$ above 900 $\mathrm{mb}$. This negative gradient of absolute vorticity is mainly caused by the horizontal wind shear of the zonal flow.

The existence of the negative $\partial \bar{q} / \partial y$ suggests that the zonal wind over the Bay of Bengal could be dynamically unstable. To confirm this possibility we examine a stability analysis for the zonal flow. Since we do not have sufficient data in the upper troposphere over the Bay of Bengal and the negative gradient of the absolute vorticity of the zonal flow in Fig. 15 is mainly caused by the horizontal wind shear as stated previously, we study the instability of the zonal flow averaged in the lower layer between $950 \mathrm{mb}$ and $500 \mathrm{mb}$. The same linearized vorticity equation without divergence and the method as Yanai and Nitta (1968) are used to obtain growth rate and structure of the unstable wave. Fig. 16 shows the distribution of the layer-averaged zonal flow and the growth rate curve as functions of the wavelength. The westerly has maximum at about $14^{\circ} \mathrm{N}$ and decreases with latitudes. $\beta-d^{2} \bar{u} / d y^{2}$ changes its sign at $17^{\circ} \mathrm{N}$ and the necessary condition for the barotropic instability is satisfied. There exists the most unstable wave at $L=$ $3,500 \mathrm{~km}$ with $e$-folding time of about 5 days. The wavelength for the most unstable wave $(\sim 3,500 \mathrm{~km})$ seems to be longer than that of the observed depression $(\sim 2,000 \mathrm{~km})$. However, since the distribution of $\bar{u}$ in Fig. 16 is somewhat smoothed by the vertical averaging, the wavelength for the most unstable wave could be shorter than that in Fig. 16 if the $\bar{u}$-distributions at individual levels are used. Also the growth rate of the unstable wave could be larger for the dis.ri'butions of $\bar{u}$ at individual levels.

The strcam funztion of the most unstable wave

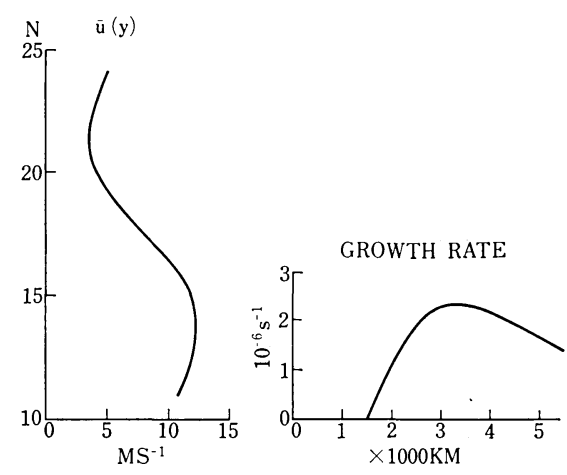

Fig. 16 Distribution of the zonal wind averaged over longitudes from $83^{\circ} \mathrm{E}$ to $93^{\circ} \mathrm{E}$ and layers from $950 \mathrm{mb}$ to $500 \mathrm{mb}$ on July 3 (left) and the growth rate curve for the unstable waves as functions of wavelength (right).

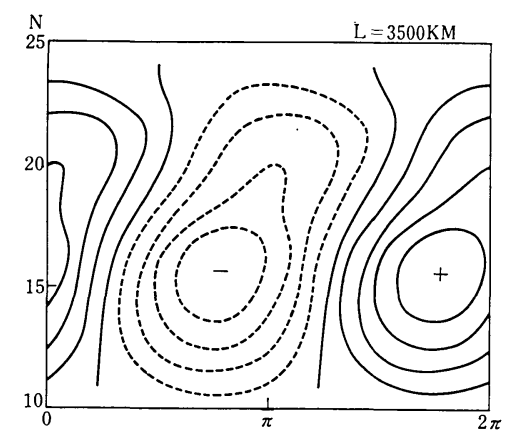

Fig. 17 Distribution of the stream function for the unstable wave with the wavelength of $3,500 \mathrm{~km}$.

is shown in Fig. 17. The unstable wave has maximum amplitude at about $16^{\circ} \mathrm{N}$ which is slightly to the south of the area of the depression formation. The wave tilts from southwest to northeast indicating northward momentum transport. The results of the horizontal inclination of the unstable wave and the northward momentum transport agree well with those for the observed depression.

The unstable wave generated by the barotropic instability of the zonal mean flow has similar characteristics to those of the observed depression in general, but there exist several deficiencies of the unstable wave by comparison with the observed depression. The first deficiency is that the unstable wave propagates eastward with about $5 \mathrm{~m} \mathrm{~s}^{-1}$ in contrast to the slow westward movement with about $2 \mathrm{~m} \mathrm{~s}^{-1}$ of the real depression. Th: unstable wave has a steering level in the lower trop sphere below $500 \mathrm{mb}$ where instability 
occurs, but the observed depression appears to have a steering level above $500 \mathrm{mb}$. This suggests possibilities that the depression may be generated by the dynamical instability of the zonal flow above $500 \mathrm{mb}$ or the heating by convective clouds may play an important role in initiation of the depression as well as the dynamical instability in the lower troposphere. These possibilities should be further examined in future.

Krishnamurti et al. (1977) examined the sequence of events for tropical downstream amplification and viewed the formation of a monsoon depression as an interaction of the large-scale standing oscillation with westward propagating smaller scale disturbances. Saha and Shukula (1980) analyzed daily sea level pressure and upper winds along a mean latitude of about $20^{\circ} \mathrm{N}$ in southeast Asia during summer MONEX and found that all the four disturbances which initially appeared in the Bay of Bengal were associated with tropical disturbances which propagated from the east. It may be possible that a westward propagating disturbance amplifies due to a strong horizontal wind shear when it comes into the Bay of Bengal. Further investigations would be needed to clarify this possibility.

Another deficiency of the stability analysis in this study is that the wavelength of the most unstable wave $(\sim 3,500 \mathrm{~km})$ is much longer than the longitudinal length $(\sim 1,000 \mathrm{~km})$ which is used to obtain the mean zonal wind. This contradicts the assumption of the constancy of the mean zonal flow in longitudinal direction for the stability analysis. As a matter of fact, Fig. 14(a) shows that the wind field varies in the longitudinal direction over the analyzed domain. It is needed to perform a stability analysis using a mean flow which varies not only in meridional but also zonal directions to see how characteristics of the instability change.

\section{Conclusions and remarks}

Three-dimensional structure of the monsoon depression during the period from the preformation stage to the developing stage is examined by the objective analysis based on the dropwindsonde observations taken during summer MONEX in 1979.

The depression forms over the Bay of Bengal in the barotropically unstable zonal wind field on July 6 and propagates westward with about $2^{\circ}$ day $^{-1}$ speed. The depression has the largest relative vorticity of about $1.5 \times 10^{-4} \mathrm{~s}^{-1}$ in the lower troposphere, and the upward motion to the west and the downward motion to the east of the center, respectively. The depression inclines slightly southwestward with height and the warm air lies or and to the east of the center. The horizontal trough axis of the depression tilts from southwest to northeast and the horizontal inclination increases with time. The depression transports the westerly momentum northward and gains its kinetic energy from the mean zonal flow. The depression also transports heat northward up the gradient of the mean temperature.

The analysis during the pre-formation period reveals that the large positive vorticity with values of about $5 \times 10^{-5} \mathrm{~s}^{-1}$ exists over the Bay of Bengal and the depression forms slightly to the north of it. This large vorticity is resulted from both the cyclonic circulation due to the weak trough and the north-south gradient of the zonal flow over the Bay of Bengal.

The necessary condition for the dynamical instability is satisfied for the zonal flow averaged over the Bay of Bengal during the pre-formation period. The stability analysis using the layeraveraged zonal flow shows that there exist barotropic unstable waves with the maximum growth rate at the wavelength of $3,500 \mathrm{~km}$. The structure of the unstable wave shows similar features to those observed such as horizontal inclination of the circulation from southwest to northeast and the northward momentum transport. However, the unstable wave propagates eastward in contrast to slow westward movement of the observed depression. Another effects such as diabatic heating, dynamical instability in the upper troposphere and westward propagating disturbances on initiation of the depression should be further examined.

\section{Acknowledgements}

We wish to express our gratitude to Dr. M. Murakami for providing valuable information regarding observational data used in this study. We are grateful to Mr. J. Ishida and $\mathrm{Mr}$. Y. Nishi for making computer programs for the objective analysis. We also thank Mrs. K. Kudo for typing the manuscript.

\section{References}

Charney, J.G., and M.E. Stern, 1962: On the stability of internal jets in a rotating atmosphere. J. Atmos. Sci., 19, 159-172.

Cressman, G., 1959: An operational objective analysis system. Mon. Wea. Rev., 94, 367-374.

Godbole, R. V., 1977: The composite structure of 
the monsoon depression. Tellus, 29, 25-40.

Krishnamurti, T. N., M. Kanamitsu, R. Godbole, C.-B. Chang, F. Carr and J.-H. Chow, 1975: Study of a monsoon depression (I). Synoptic structure. J. Meteor. Soc. Japan, 53, 227-239.

1976: Study of a monsoon depression (II). Dynamical structure. J. Meteor. Soc. Japan, 54, 208-225.

, J. Molinari, H.-L. Pan and V. Wong, 1977: Downstream amplification and formation of monsoon disturbances. Mon. Wea. Rev., 105, 1281-1297.

Nitta, T., and M. Murakami, 1980: Three dimensional structure and energy cycles of a monsoon depression developed over the Bay of Bengal. FGGE Operation Report 9, 137-144.
Ogura, Y., Y.-L. Chen, J. Russell and S.-T. Soong, 1979: On the formation of organized convective systems observed over the eastern Atlantic. Mon. Wea. Rev., 107, 426-441.

Saha, K., and J. Shukla, 19.80: Further evidence of association of westward-propagating disturbances with monsoon depressions. FGGE Operation Report, 9, 23-31.

Shukla, J., 1977: Barotropic-baroclinic instability of mean zonal wind during summer monsoon. Pure Appl. Geophys., 115, 1449-1462.

- 1978: CISK-barotropic-baroclinic instability and the growth of monsoon deperssions. J. Atmos. Sci., 35, 495-508.

Yanai, M., and T. Nitta, 1968: Finite difference approximations for the barotropic instability problem. J. Meteor. Soc. Japan, 46, 389-403.

\title{
夏季モンスーン実験期間中, ベンガル湾上で 発達したモンスーン低気圧の解析
}

\author{
新田就・增田耕一 \\ 東京大学理学部地球物理学教室
}

夏季モンスーン実験期間中，ベンガル湾上で発達したモンスーン低気圧の三次元構造を，飛行機によるドロッ プゾンデ観測と, 通常の高層観測データを用いて調べた。1979 年 7 月 3 日〜 8 日の期間, 領域 $11^{\circ} \mathrm{N} \sim 24^{\circ} \mathrm{N}$, $80^{\circ} \mathrm{E} \sim 93^{\circ} \mathrm{E}$ 飞打ける地上から $500 \mathrm{mb}$ の風, 気温, 相対湿度のデータを客観解析の手法で水平 $1^{\circ}$, 垂直 $25 \mathrm{mb}$ ごとの格子点に内插した。

低気圧は 7 月 6 日, ベンガル湾上 $19^{\circ} \mathrm{N}, 90^{\circ} \mathrm{E}$ 付近に発生し, 約 $2^{\circ}$ /日の速度で西進し, 7 月 8 日にはイン ド大陸の西海岸に到達した。発達した低気圧は, 約 $1.5 \times 10^{-4} \mathrm{~s}^{-1}$ の最大渦度を持ち, 中心のやや東側に暖域が 存在する。中心の西側には, 水平収束と上昇域があり, ここには活発な積雲対流が存在している。低気圧の水平 軸は南西から北東に傾き，運動量および影熱を北に輸送しており，平均流から運動エネルギーを得ている。

低気圧の発生前にベンガル湾上には $5 \times 10^{-5} \mathrm{~s}^{-1}$ の比較的大きな正の相対渦度が存在しており，低気圧はこの 領域のすぐ近傍で発生した。この大きな相対渦度は, 弱いトラフの存在と, 東西風の南北変化によってできてい る。

発生前のベンガル湾上の東西風の南北 - 垂直分布を調べてみると, 平均流は不安定の必要条件を満たしている ことがわかった。さらに $500 \mathrm{mb}$ 以下の層で平均した東西風の安定性を調べてみると, 順圧不安定による不安定 波が存在し, 波長 $3,500 \mathrm{~km}$ 付近に増幅率最大を持っている。この不安定波はいくつかの点で観測されたモンス ーン低気圧と類似した特性を有している。 